\title{
Uterine Perforation on Invasive Hydatidiform Mole during EMACO Treatment
}

\author{
Perforasi Uterus pada Mola Hidatidosa Invasif saat Tatalaksana EMACO \\ Bram Pradipta, Andrijono, Sigit Purbadi, Tofan W Utami \\ Division of Gynecologic Oncology \\ Department of Obstetrics and Gynecology \\ Faculty of Medicine University of Indonesia/ \\ Dr. Cipto Mangunkusumo Hospital \\ Jakarta
}

\begin{abstract}
Objective: Improving skill and knowledge to recognize and manage a rare case of uterine perforation on invasive hydatidiform mole.

Method: Case report.

Result: A 42 years old Indonesian woman, Parity 2 Abortus 2 with history of 2 c-sections and 2 curettage, came with chief complaint of recurrent vaginal bleeding since 4 months before admission. Patient had a history of previous curettage with indication of hydatidiform mole and recurrent bleeding with no histopathology results. On examination we found a vesicular mass with infiltration, destroying the right-front uterine corpus, size $8 \times 6 \mathrm{~cm}$ with an internal echo mass. Chest $\mathrm{x}$-ray showed multiple nodules in the lung. The patient, considered as low risk Gestational Trophoblastic Neoplasia patient with FIGO Score of 6, underwent chemotherapy with 2 series of methotrexate . Due to the non-declining level of -hCG, theregimen was added with EMACO. In the process of chemotherapy, the pa-tient's -hCG declined but then she complained of major abdominal pain. Exploratory laparotomy was performed and we found a mass sized $5 \times 5 \times 5$ $\mathrm{cm}$ on the right side of the uterus at the broad ligament with a rupture at the posterior part of the mass sized $0.5 \times 0.5 \mathrm{~cm}$. Upon incision of the uterus, we found a mass from the right side protruding to the isthmus of the uterus. Histopathology showed necrosis, blood and chorionic villi in myometrium corresponding to invasive mole. Patient was then given another 5 series of EMACO and her condition was unremarkable during the remaining course of treatment.
\end{abstract}

Conclusion: Invasive mole treatment is determined based on the risk factors. Uterine perforation still occurred in this case regardless of the decreasing hCG level during EMACO treatment. It emphasizes the importance of clinical examination as chemotherapy responsiveness. Long-term treatment can have a good prognosis but good collaboration between the gynecologist and the patient is essential.

[Indones J Obstet Gynecol 2014; 3: 162-165]

Keywords: EMACO, invasive mole, perforation

\section{Abstrak}

Tujuan: Meningkatkan pengetahuan dan kemampuan untuk mengenali dan menangani kasus perforasi uterus pada mola hidatidosa invasif.

Metode: Laporan kasus.

Hasil: Seorang perempuan Indonesia berusia 42 tahun, Paritas 2 Abortus 2 dengan riwayat 2 seksio sesarea dan 2 kuretase, datang dengan keluhan utama perdarahan pervaginam berulang sejak 4 bulan sebelumnya. Pasien memiliki riwayat kuretase sebelumnya atas indikas mola hidatidosa dan perdarahan berulang tanpa disertai hasil histopatologi. Pada pemeriksaan kami menemukan massa vesikular yang infiltratif dan menghancurkan korpus uterus kanan depan, berukuran 8x6 $\mathrm{cm}$ dengan struktur ekhointerna. Rontgen dada menunjukkan beberapa nodul di paru-paru. Pasien didiagnosa sebagai pasien penyakit trofoblas gestasional risiko rendah dengan Skor FIGO 6 dan diberi kemoterap dengan 2 seri methotrexat. Karena kadar -hCG yang tidak menurun rejimen ditambahkan dengan EMACO. Dalam proses kemoterapi, kadar -hCG menurun tapi kemudian mengalami keluhan nyeri perut yang berat. Laparotomi eksplorasi dilakukan dan ditemukan massa berukuran 5 × 5 × $5 \mathrm{~cm}$ di sisi rahim tepat pada ligamen latum dengan bagian posterior massa telah pecah berukuran $0,5 \times 0,5 \mathrm{~cm}$ Pada rahim didapatkan massa menonjol ke bagian isthmus. Hasil histopatologi menunjukkan bagian nekrosis, darah dan villi korialis dalam miometrium sesuai dengan mola invasif. Pasien kemudian diberi terapi EMACO selama 5 siklus dengan kondisi baik selama jangka waktu pengobatan.

Kesimpulan: Pengobatan mola invasif diklasifikasikan tergantung faktor risiko untuk menentukan tatalaksana. Perforasi uterus masih terjadi dalam kasus ini meskipun tingkat hCG terus menurun selama pengobatan EMACO. Hal tesebut menekankan pentingnya pemeriksaan klinis dalam menilai respons kemoterapi. Tata laksana bisa dilakukan jangka panjang dengan prognosis yang baik dengan kerjasama yang baik antara dokter dan pasien.

[Maj Obstet Ginekol Indones 2014; 3: 162-165]

Kata kunci: EMACO, mola invasif, perforasi

Correspondence: Bram Pradipta. Department of Obstetrics and Gynecology. Faculty of Medicine University of Indonesia, Jakarta. Telephone: 081908065679. Email: bram_p@yahoo.com

\section{INTRODUCTION}

Gestational trophoblastic diseases are a heterogenous group of conditions ranging from the benign hydatidiform mole to the malignant choriocarcinoma with complete hydatidiform mole occurring in around 1 per 1,000 conceptions. ${ }^{1}$ Invasive mole is a condition where a molar pregnancy, such as a partial hydatidiform mole or complete hydatidiform mole, invades the wall of the uterus, potentially spreading and metastasizing to other parts of 
the body. ${ }^{2}$ It comprises only about $5-8 \%$ of all gestational trophoblastic neoplasia (GTN). ${ }^{3}$ Here we present a case of an Indonesian woman with uterine perforation because of invasive mole in the process of undergoing chemotherapy with methotrexate and even with EMACO.

\section{CASE ILLUSTRATION}

\section{History, Examination and Management}

We report a case of a 42-years old Indonesian woman who came to our hospital with chief complaint of recurrent vaginal bleeding since 4 months prior to admission. Patient had a history of two prior curettage in other hospital, 4 months and 2 months before, with indication of hydatidiform mole and recurrent bleeding, respectively. Unfortunately no tissues were checked for pathology examination. Patient's obstetric history included 2 cesarean sections and 2 curettage on her previous pregnancies.

On physical examination, we found the patient's condition to be unremarkable. On gynecological examination we found that the uterus was enlarged with suspected adnexal mass on the right adnexa. On ultrasonography we found a vesicular mass that infiltrated and destroyed the right-front uterine corpus, sized $8 \times 6 \mathrm{~cm}$ with an internal echo mass, blood like structure inside. Chest $\mathrm{x}$-ray showed multiple nodules in the lung.

The patient was then considered as low risk GTN patient with FIGO Score of 6 . She then underwent chemotherapy with two series of methotrexate. The baseline hCG level was 99,947 IU/ml. After the first methothrexate, it decreased to $58,000 \mathrm{IU} / \mathrm{ml}$ but then increased to $69,100 \mathrm{IU} / \mathrm{ml}$ after the second dose. Because of that, the regimen was added with EMACO. After the $1^{\text {st }}$ EMACO, the patient's hCG declined to $11,854 \mathrm{IU} / \mathrm{ml}$ but then she complained of major abdominal pain. We then performed an exploratory laparotomy and found a mass sized $5 \times 5 \times 5 \mathrm{~cm}$ in the right side of the uterus at the broad ligament with a rupture at the posterior part of the mass sized $0.5 \times 0.5 \mathrm{~cm}$. Both of the tubes and ovaries were within normal limits. Upon incision of the uterus, we found a mass from the right side protruding to the isthmus of the uterus.

Patient was then given another 5 series of EMACO and -hCG continued to decline to as low as $1.45 \mathrm{IU} / \mathrm{ml}$. The patient's condition was unremarkable during the remaining course of treatment.

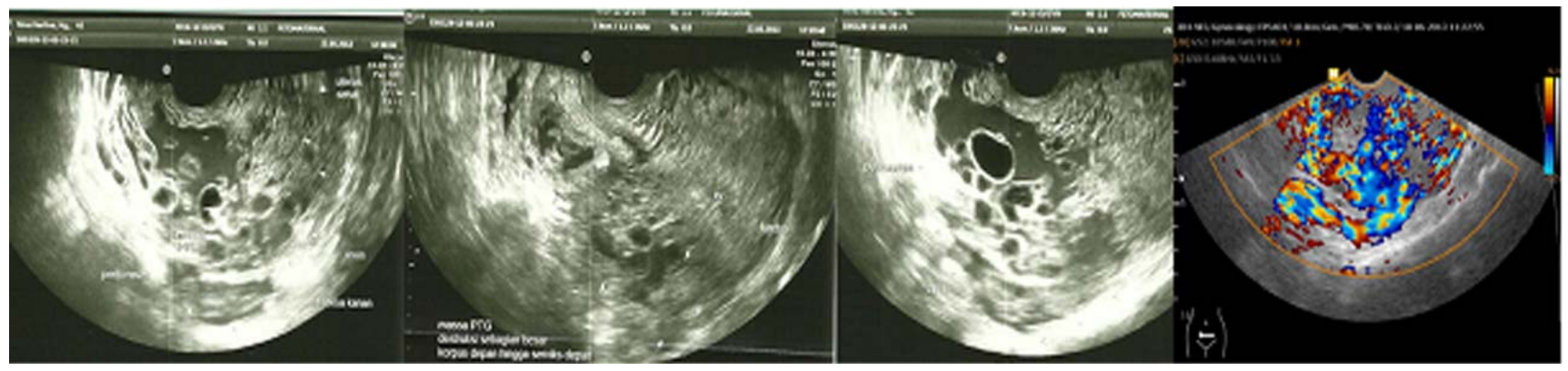

Figure 1. Ultrasonography results: Malignant Trophoblastic that Invades the Right Uterine Corpus and Adnexa.
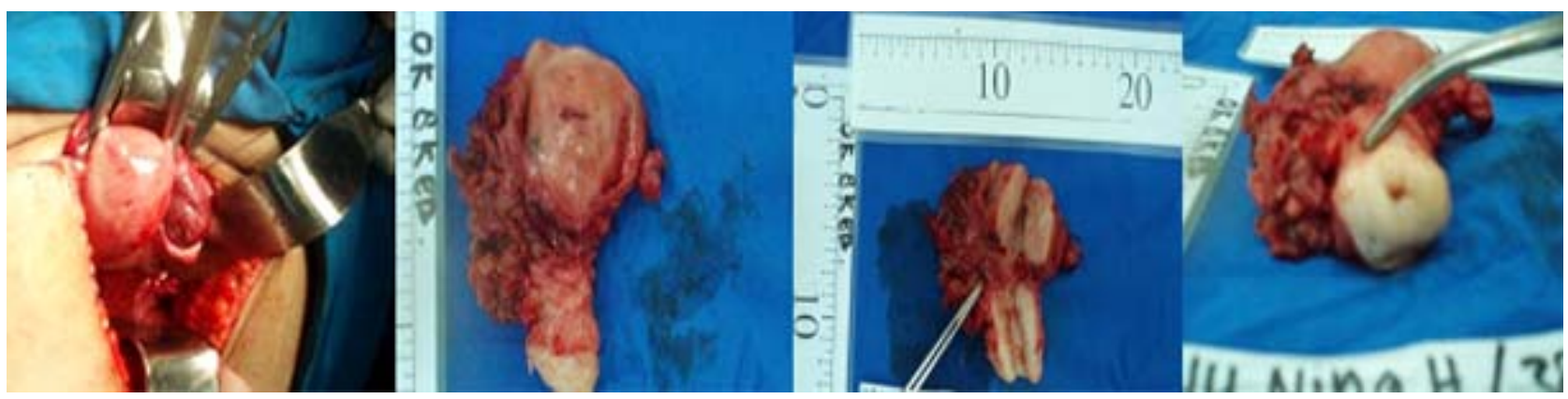

Figure 2. Intraoperative Finding Showing Mass with a Rupture at the Posterior Part. 


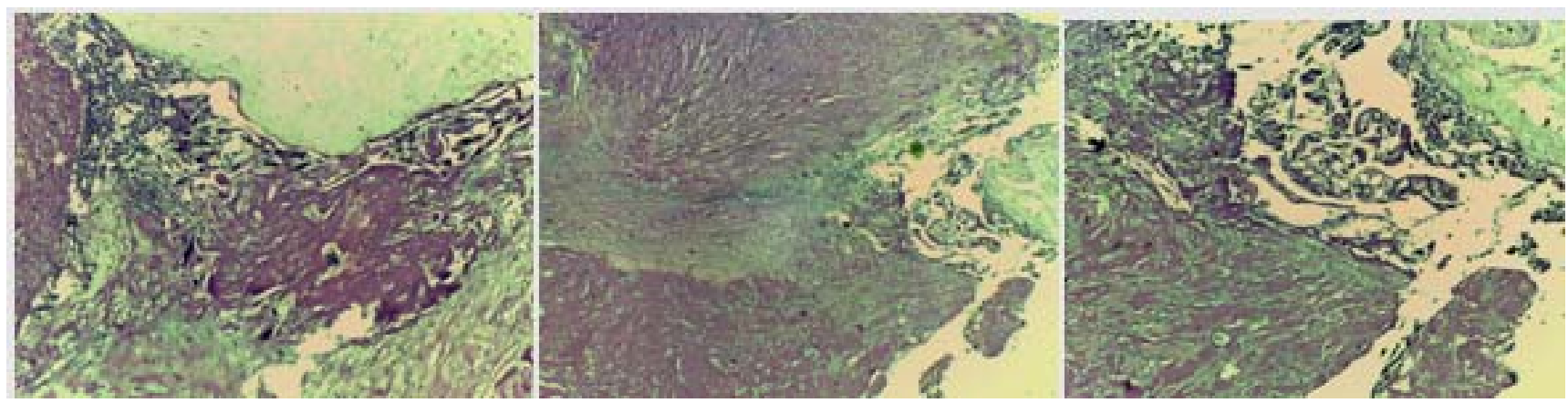

Figure 3. Histopathology Showed Necrosis, Blood and Villi Chorialis in Myometrium Corresponding to Invasive Mole.

\section{DISCUSSION}

Invasive mole is a condition where a molar pregnancy, such as a partial hydatidiform mole or complete hydatidiform mole, invades the wall of the uterus, potentially spreading and metastasizing to other parts of the body (such as the vagina or lungs). ${ }^{2,4,5}$ Its clinical characteristic are heterogenous. ${ }^{4}$ Untreated invasive moles tend to invade the uterine wall locally, which can result in uterine perforation and hemorrhage. ${ }^{6-8}$ It is characterized by the persistence of edematous chorionic villi with trophoblastic proliferation invading into the myometrium..$^{9}$ The presence of villi in the trophoblastic tissue differentiates an invasive mole from choriocarcinoma. $3,9,10$

GTN is considered the most curable gynecologic malignancy. ${ }^{11}$ The management of low-risk metastatic GTN are similar to that of non-metastatic with very good response of single agent chemotherapy and those who fail can be treated with alternative single agent or combination chemotherapy. ${ }^{5}$ Our patient had a FIGO score of 6 and was considered as low risk GTN. Data from a single center showed that patients with a low-risk FIGO score but with an hCG value exceeding 100,000 $\mathrm{mIU} / \mathrm{ml}$ frequently require combination chemotherapy. ${ }^{12}$ The failure of treatment with methotrexate increased the score to 8 in our patient and she was then considered as high risk. Chemoresistant case is when the patient had a plateau $(<50 \%$ fall in the $-\mathrm{hCG}$ levels) or an increased -hCG level and/or development of new metastases for at least two consecutive cycles of combined chemotherapy. ${ }^{13}$

EMACO has the best effectiveness-to-toxicity ratio, hence making it the first line regiment of combination chemotherapy. ${ }^{14}$ Patients with disease resistant to EMACO can be treated using EMAEP, a regimen that substitutes cyclophosphamide and vincristine on day 8 with cisplatin and etoposide. ${ }^{14}$ Our patient had a lowered -hCG level from 69,000 to 11,000 in the EMACO process, but clinically the patient had abdominal pain that was later shown as a uterine perforation. Serum hCG level is the most relevant parameter in GTN detection as well as in checking the efficacy of administered therapy. ${ }^{15}$ In our case, -hCG levels seem to respond to the chemotherapy with the decreasing level but uterine perforation still occurred, which emphasized the importance of clinical examination to assess chemotherapy responsiveness. Chemoresistance may not be the case for our patient. Other regimens that were also effective in treating highrisk refractory GTN includes BEP (bleomycin, etoposide, cisplatin), ICE (ifosfamide, carboplatin, etoposide), VIP (etoposide, ifosfamide, cisplatin) and also FAEV (floxuridine, dactinomycin, etoposide, and vincristine). ${ }^{14,16}$ Patients with chemoresistant GTN have a bad prognosis and worse outcome compared with patients with relapsed GTN. ${ }^{13}$

As far as we know, there have not been any case reports on cesarean scar site of invasive mole. There are no clear guidelines for the management of cesarean scar site molar pregnancy. Current literature reveals ultrasound-guided suction evacuation to be the most widely used method and the most successful. ${ }^{17}$ Moreover, some have adviced use of oxytocyin during curettage. ${ }^{18}$

\section{CONCLUSION}

Invasive mole is a rare case with heterogenous presentation. Its treatment are grouped between the risk factor that should be counted beforehand to determine its therapy. The uterine perforation still occurred in this case despite the decreasing hCG level during EMACO treatment. It emphasizes the importance of clinical examination to assess 
chemotherapy responsiveness. Long-term treatment can yield good prognosis but good collaboration between the gynecologist and the patient is essential, as well as the need for support.

\section{REFERENCES}

1. Wolfberg AJ, Feltmate C, Goldstein DP et al. Low risk of relapse after achieving undetectable HCG levels in women with complete molar pregnancy. Obstet Gynecol 2004; 104: 551-4.

2. Kittur S, Venktesh, Ramlingappa A. A rare case of invasive mole with silent uterine perforation. Int J Reprod Contracept Obstet Gynecol 2013; 2(1): 109-10.

3. Abha S, Rekhaa R. Heterogenous Presentation of Chorioadenoma Destruens. J Obstet Gynecol Ind 2012; 62: 71-4.

4. Singh S, Kaur N, Joshi S. Invasive mole presenting as pain abdomen. Int J Reprod Contracept Obstet Gynecol 2013; 2(3): 480-1.

5. Ilancheran A. Optimal Treatment in Gestational Trophoblastic Disease. Ann Acad Med Singapore 1998; 27: 698704.

6. Chhabra S, Qureshi A. Gestational trophoblastic neoplasms with special reference to invasive mole. Obstet Gynecol Ind 2007; 57(2): 124-7.

7. Kumar S, Vimala N, Mittal S. Invasive Mole Presenting as Acute Haemoperitoneum. JK Science 2004; 6(3): 159.

8. RCOG. The Management of Gestational Trophoblastic Disease. Green Top Guidelines 2010; 38.

9. Lurain JR. Gestational trophoblastic disease I: epidemiology, pathology, clinical presentation and diagnosis of gestational trophoblastic disease, and management of hydatidiform mole. Am J Obstet Gynecol 2010; 203(6): 531-9.
10. Dollinger M, Rosenbaum EH, Tempero M, Mulvihill S. Trophoblastic Disease 2001; $4^{\text {th }}$ ed. P:1-16.

11. Burger RA, Creasman WT. Gestational Trophoblastic Neoplasia. In: Disala PJ, Creasman WT (eds). Clin Gynecol Oncol $6^{\text {th }}$ ed. Philadelphia: Mosby Inc. 2000: 185-210.

12. McGrath S, Short D, Harvey R, Schmid P, Savage PM, Seckl MJ. The management and outcome of women with post-hydatidiform mole 'low-risk' gestational trophoblastic neoplasia, but hCG levels in excess of 100000 IU. Bri J Cancer 2010; 102: 810-4.

13. Feng F, Xiang Y, Wan X, Zhou Y. Prognosis of patients with relapsed and chemoresistant gestational trophoblastic neoplasia transferred to the Peking Union Medical College Hospital. BJOG 2010; 117: 47-52.

14. May T, Goldstein DP, Berkowitz RS. Current chemotherapeutic management of patients with gestational trophoblastic neoplasia. Chemo Res Pract. 2011: 1-12.

15. Tidy J, Gillespie AM, Bright N et al. Gestational trophoblastic disease: a study of mode of evacuation and subsequent need for treatment with chemotherapy. Gynecol Oncol 2000; 78: 309-12.

16. Feng F, Xiang Y, Wan X et al. Salvage combination chemotherapy with floxuridine, dactinomycin, etoposide, and vincristine (FAEV) for patients with relapsed/chemoresistant gestational trophoblastic neoplasia. Annals Oncol 2011; 22(7): 1588-94.

17. Kaluarachchi CI, Tissera AJ, Karunarathna SMGG. Caesarean scar site complete molar pregnancy. Sri Lanka J Obstet Gynecol 2013; 35: 62-4.

18. Jin FS, Ding DC, Wu GJ, Hwang KS. Molar pregnancy in a cesarean section scar of uterus. J Med Sci 2011; 31(4): 173-6. 